\title{
REVIEW
}

\section{Regulation of body mass and adiposity in the field vole, Microtus agrestis: a model of leptin resistance}

\author{
Elżbieta Król and John R Speakman \\ Aberdeen Centre for Energy Regulation and Obesity (ACERO), School of Biological Sciences, University of Aberdeen, Aberdeen AB24 2TZ, UK \\ (Requests for offprints should be addressed to J R Speakman; Email: j.speakman@abdn.ac.uk)
}

\begin{abstract}
Adult mammals are typically highly resistant to perturbations in their energy balance. In obese humans, however, this control appears to be lost. Apart from a few exceptional cases, this loss of control occurs despite appropriate levels of circulating leptin - suggesting that elevated adiposity may be a consequence of failure to respond to the leptin signal: leptin resistance. When cold-acclimated male field voles (Microtus agrestis) are transferred from short (SD, $8 \mathrm{~h}$ light) to long (LD, $16 \mathrm{~h}$ light) photoperiods, they increase dramatically in body mass and fatness for about 4 weeks. After this period, their mass stabilizes at a new plateau about 25\% higher than animals maintained in SD. The increase in adiposity is not caused by significant increases in food intake, but reflects an increase in digestive efficiency. Measures of circulating leptin reveal that the increased adiposity is matched by increased circulating leptin. By infusing voles with exogenous leptin, we have demonstrated that SD voles are leptin sensitive (reducing both body mass and food
\end{abstract}

intake), whereas LD animals are leptin resistant. Voles may therefore be a useful model for understanding the process of leptin resistance. The change in leptin sensitivity in voles was not associated with changes in the levels of gene expression of the orexogenic or anorexogenic neuropeptides, such as neuropeptide $\mathrm{Y}$, agouti-related peptide, POMC and cocaine- and amphetamine-regulated transcript, measured in the hypothalamic arcuate nucleus (ARC). During the phase that body mass was increasing, however, there was a transient increase in the $A R C$ expression of suppressor of cytokine signalling-3 (SOCS3). These data suggest that the changes in the expression of SOCS 3 in the ARC may be involved in leptin resistance. However, the mechanism by which these changes may be linked to alterations in digestive efficiency that underpin the changes in adiposity, or how the differences are signalled by changes in photoperiod, remains unclear.

Journal of Endocrinology (2007) 192, 271-278

\section{Introduction}

There is a widespread belief that body mass and body fatness are regulated phenomena. This stems from observations in many mammal species that adult body mass and body fatness remain stable over protracted periods of time, in spite of changes in the availability and quality of food and levels of energy expenditure (Stallone \& Stunkard 1991, Rosenbaum et al. 1997, Schwartz \& Seeley 1997, Levin \& Keesey 1998). The exact nature of the system regulating body mass and fatness, however, remains unclear, and a number of alternative models have been proposed that are all broadly consistent with the existing data (reviewed in Mercer \& Speakman 2001, Speakman 2004). One model, originally proposed by Kennedy (1953) is that body fatness is regulated by a lipostatic system. In this system, body fat generates a signal that travels to the brain where it is compared with a target. Deviations of the adiposity signal away from the target, trigger compensatory responses in energy intake and expenditure, which restore the defended level of body fatness (Schwartz et al. 2000). The discovery of the adipokine leptin (Zhang et al. 1994) and the signalling form of its receptor LRb (Tartaglia et al. 1995) provided a candidate molecular basis for the lipostatic control of adiposity. Subsequent characterization of the signalling system downstream from LRb, involving both orexogenic and anorexogenic neuropeptides located in the various nuclei of the hypothalamus, has greatly strengthened support for the lipostatic model of body fatness regulation (Schwartz et al. 2000, Berthoud 2002).

Obese humans do not appear to have the capability to regulate their weight and adiposity. Yet, apart from a few unusual cases (e.g. Montague et al. 1997), their adipose tissue seems to generate an appropriate leptin 'adiposity' signal (Considine et al. 1996). Treating humans that already have high levels of circulating leptin with recombinant leptin generates significant weight loss, but much less than might be 
anticipated if the lipostatic signalling system were intact (Heymsfield et al. 1999). Focus of attention has therefore primarily been directed to understanding why the leptin signal from fat tissue does not generate an appropriate regulatory response - the so-called phenomenon of 'leptin resistance'.

Many small mammals inhabiting temperate and arctic regions exhibit annual cycles in body mass and adiposity (e.g. Heldmaier \& Steinlechner 1981, Stebbins 1984, Bartness \& Wade 1985, Klingenspor et al. 1996, Bartness et al. 2002, Drazen et al. 2002). These seasonal changes are associated with corresponding alterations in circulating leptin. The seasonal change in body adiposity in animals, which are normally highly resistant to perturbations in their energy balance, provides a potentially useful model for exploring the phenomenon of leptin resistance. Since many of these annual changes require time to develop, they must be initiated in anticipation of the forthcoming season and many rodents rely on environmental cues such as increasing or decreasing day lengths to initiate the changes (e.g. Dark et al. 1983, Mrosovsky 1983, Bartness et al. 2002). The responses to changing photoperiod can be readily induced in the laboratory by acutely transferring animals between longand short-day lengths. This amenability to manipulation makes such species attractive to study, and they may provide valuable insights into the mechanisms underlying regulation of body mass (Mercer \& Speakman 2001, Bartness et al. 2002, Schuhler \& Ebling 2006).

Although seasonal patterns of changes in body mass and fatness occur in a variety of mammalian species, they have been studied most extensively in the Siberian or Djungarian hamster (Phodopus sungorus; Steinlechner \& Heldmaier 1982, Bartness \& Goldman 1988, Ebling 1994, Klingenspor et al. 2000, Mercer et al. 2000, 2001), Syrian or golden hamster (Mesocricetus auratus; Campbell \& Tabor 1983, Bartness \& Wade 1985) and collared lemming (Dicrostonyx groenlandicus; Reynolds \& Lavigne 1989, Nagy 1993, Nagy \& Negus 1993 , Nagy et al. 1994, Hunter \& Nagy 2002). Some of these studies suggest that long-term physiological state is adjusted to a continuously altered set point that is regulated by seasonal changes in day length. The concept of the sliding body mass set point has been summarized in several previous reviews (e.g. Morgan \& Mercer 2001, Bartness et al. 2002, Morgan et al. 2003, Schuhler \& Ebling 2006). In the current review, we summarize our work on a novel seasonal model of leptin resistance - the field vole (Microtus agrestis; Król et al. 2005, 2006, 2007). The review is structured in three parts. In part one, we describe the general features of the photoperiodinduced changes in adiposity in the field vole, and measurements that reveal the energetic basis for the increase in fat mass. In the second part, we show that voles change their leptin sensitivity under different photoperiod regimes. Finally, we present some data on gene expression in the hypothalamic arcuate nucleus (ARC), a key site of both leptin signalling in the brain (Schwartz et al. 2000) and regionspecific leptin resistance (Münzberg et al. 2004).

\section{Photoperiod-induced adiposity in the field vole - energetics aspects}

The pattern of change in body mass of cold-acclimated voles transferred from short-day (SD, $8 \mathrm{~h}$ light) to long-day (LD, $16 \mathrm{~h}$ light) photoperiod is illustrated in Fig. 1. During exposure to SD, body mass was stable and averaged $25 \cdot 6 \pm$ $3 \cdot 3 \mathrm{~g}$. However, on exposure to LD, body mass increased from a mean of $26 \cdot 2 \pm 3 \cdot 7 \mathrm{~g}$ on day 0 to $36 \cdot 3 \pm 5 \cdot 2 \mathrm{~g}$ on day 28. Following this period of dramatic increase, the voles regained stability over their mass which then remained stable at around $37 \cdot 7 \pm 5.4 \mathrm{~g}$. This increase in body mass was associated with significant increases in the masses of all body components, including dry fat mass, dry lean mass and body water mass. At the organ level, voles killed during the plateau phase had significantly heavier dry masses of brown adipose tissue, subcutaneous, epididymal, perirenal and retroperitoneal fat depots (all $P<0 \cdot 001$ ).

Food intake of $\mathrm{LD}$ voles increased significantly throughout the experiment $(P<0 \cdot 001$, Fig. 2$)$. Prior to LD exposure (days -14 to 0 ), food intake was constant and averaged $6 \cdot 1 \pm$ $0 \cdot 8 \mathrm{~g} /$ day. Following LD exposure, voles increased their daily food intake from a mean of $6 \cdot 3 \pm 0 \cdot 9 \mathrm{~g}$ on day 0 to $7 \cdot 8 \pm 1 \cdot 2 \mathrm{~g}$ on day 28 (all comparisons between days 14-28 and days -14 to $0, P<0 \cdot 05)$. Over the next 4 weeks, food intake stabilized at a level of $8 \cdot 1 \pm 1 \cdot 2 \mathrm{~g} /$ day. The trajectory of food intake (Fig. 2) for voles exposed to LD closely resembled the changes in body mass (Fig. 1). For SD voles, daily food intake averaged $6 \cdot 2 \pm 0 \cdot 9 \mathrm{~g}$ on day -14 and $7 \cdot 2 \pm 1 \cdot 1 \mathrm{~g}$ on day 56 (Fig. 2). To investigate the effect of photoperiod on food intake in relation to changes in body mass, we compared food intake of LD voles during the pre-exposure, increase and plateau phases, including body mass as a covariate in the analysis. Once body mass was included in the model, the effect of LD on food intake was not significant (photoperiod effect, $P=0 \cdot 95$ ). This suggests that $\mathrm{LD}$ voles responded to increases in body mass by increasing their food intake rather than the reverse.

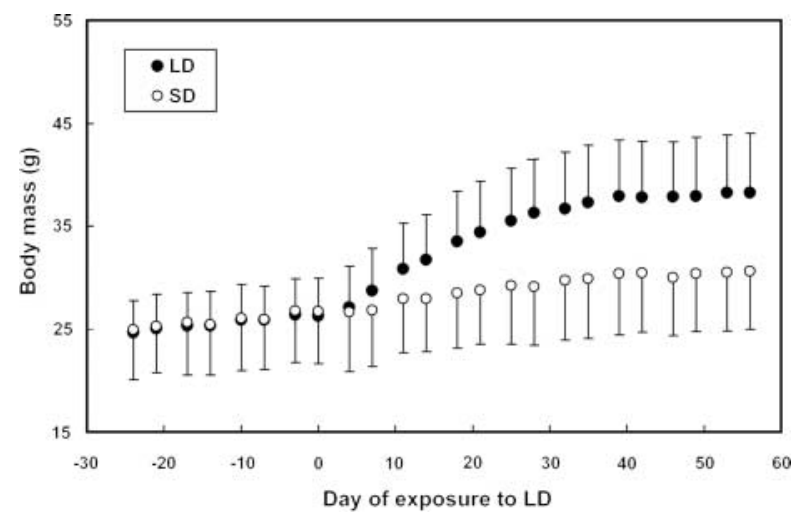

Figure 1 Effect of exposure to long-day photoperiod (LD, 16 h light) on mean body mass of 12 male field voles measured between days -24 and 56 (day 0 is the day of exposure to LD). Data for 11 voles kept in short-day photoperiod (SD, $8 \mathrm{~h}$ light) are also shown. Error bars indicate 1 S.D. 


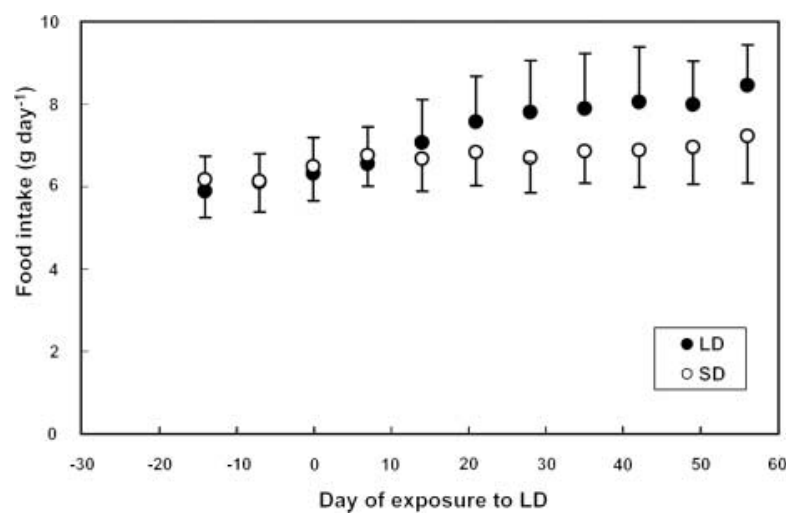

Figure 2 Effect of exposure to long-day photoperiod (LD, 16 h light) on mean food intake of 12 male field voles measured between days -24 and 56 (day 0 is the day of exposure to LD). Data for 11 voles kept in short-day photoperiod (SD, $8 \mathrm{~h}$ light) are also shown. Error bars indicate 1 S.D.

The apparent digestive efficiency (calculated as the percentage of gross energy intake that was digested) averaged $74 \cdot 2 \pm$ $5 \cdot 5 \%(n=7)$ in SD voles, $81 \cdot 4 \pm 5 \cdot 5 \%(n=8)$ in voles during the increase phase and $80 \cdot 3 \pm 4 \cdot 1 \%(n=8)$ during the plateau phase. These means were significantly different $(P=0 \cdot 031)$, with the digestive efficiency of $\mathrm{LD}$ voles during the increase and plateau phases being higher than in SD animals $(P<0 \cdot 05)$. Using the digestive efficiency data, we calculated metabolizable energy intake (MEI) for $\mathrm{LD}$ voles monitored between days -24 and 56 during the pre-exposure, increase and final plateau phases. After adjusting for differences in body mass, the effect of LD on MEI was significant (photoperiod effect, $P=0 \cdot 006$ ), with MEI during the increase and plateau phases being significantly higher than during the pre-exposure phase $(P<0 \cdot 05 ;$ Fig. 3$)$. The rate at which voles assimilated energy during the pre-exposure,

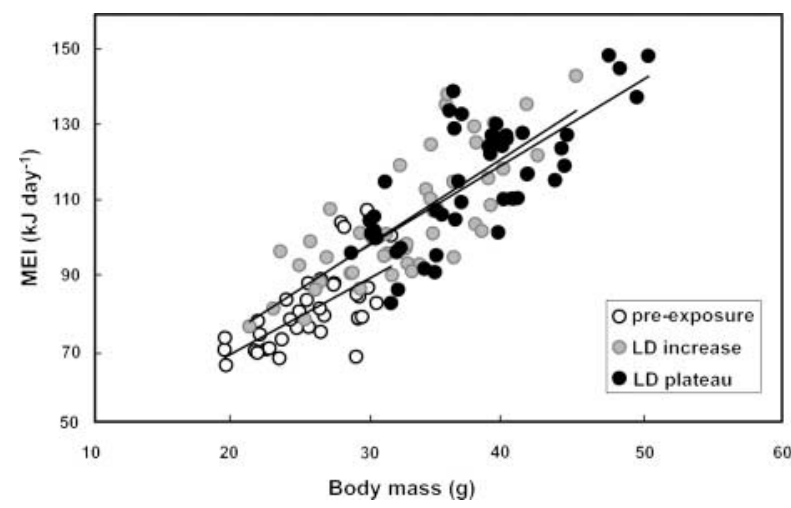

Figure 3 Metabolizable energy intake (MEI) as a function of body mass for 12 male field voles prior to exposure to long-day photoperiod (LD, $16 \mathrm{~h}$ light), during the increase phase (days 1-28 of LD exposure) and during the plateau phase (days 29-56 of LD exposure). Prior to exposure to LD, the animals were kept in shortday photoperiod (SD, $8 \mathrm{~h}$ light). After adjusting for differences in body mass, the effect of LD on MEI was significant. The relationships are described by $y=27 \cdot 7+2 \cdot 0 x$ for pre-exposure, $y=26 \cdot 0+2 \cdot 4 x$ for LD increase and $y=30 \cdot 4+2 \cdot 2 x$ for LD plateau. increase and plateau phases (adjusted to a common body mass of $32 \cdot 7 \mathrm{~g}$ ) averaged $95 \cdot 3,103 \cdot 7$ and $102 \cdot 9 \mathrm{~kJ} /$ day respectively.

\section{Circulating leptin levels and leptin resistance}

Levels of circulating leptin, in voles culled across the short- to long-day manipulation were positively correlated with dry fat mass $(r=0 \cdot 84, P<0 \cdot 001$; Fig. 4$)$. The effects of photoperiod and day of exposure on the leptin levels were not significant if fat mass was included as an independent covariate. The voles were therefore generating an appropriate leptin signal for their changing adiposity as they progressed from SD to LD.

We implanted voles in both the SD conditions and during the increasing phase of exposure to LD (day 10 postphotoperiod switch) with mini-osmotic pumps, delivering either saline (PBS) or recombinant murine leptin for 7 days. The levels of circulating leptin averaged $5 \cdot 8 \pm 1 \cdot 8$ (LD-PBS), $21 \cdot 2 \pm 10 \cdot 6$ (LD-leptin), $4 \cdot 7 \pm 1 \cdot 8$ (SD-PBS) and $24 \cdot 6 \pm 11 \cdot 5$ (SD-leptin) $\mathrm{ng} / \mathrm{ml}$ ( $n=9$ for all means).

To evaluate the effect of photoperiod and leptin treatment on body mass, we calculated a base line body mass for each vole (mean body mass for days -4 to 0 ) and expressed all masses between days 2 and 17 post-photoperiod change as the difference from the base line (Fig. 5). In LD photoperiod, the day-to-day changes in body mass of leptin-infused voles over days $2-17$ (prior to surgery and during the treatment) were not significantly different from those in PBS-infused controls. In contrast, the pattern of body mass changes in SD leptininfused voles before and after surgery was significantly different from that of SD PBS-infused animals $(P<0 \cdot 001)$. This difference was related to days 16 and 17 , when the body mass of leptin-infused voles became significantly lower than in PBSinfused controls. On average, the SD leptin-infused voles weighed $27.9 \pm 4.4 \mathrm{~g}$ on day 10 and $25.5 \pm 4.3 \mathrm{~g}$ on day 17 .

Mean food intake at the beginning of the experiment (day -4) was $6 \cdot 4 \pm 0 \cdot 8$ (LD-leptin), $6 \cdot 4 \pm 0 \cdot 9$ (LD-PBS),

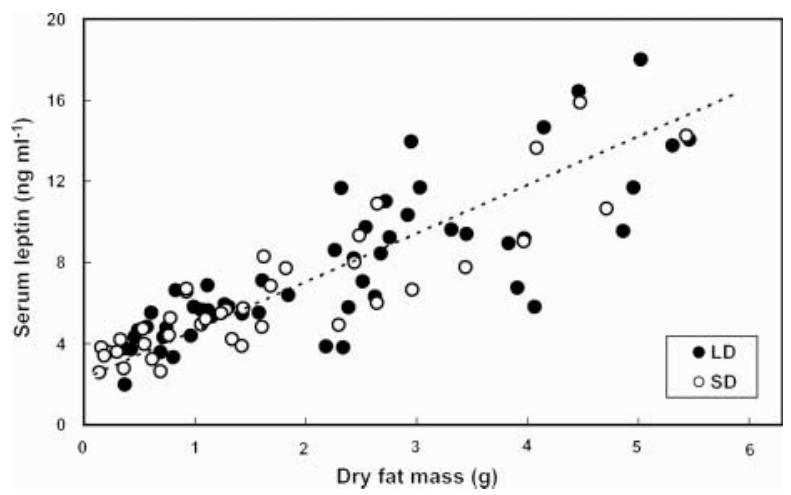

Figure 4 Serum leptin concentration plotted against the dry fat mass for male field voles exposed to either short-day photoperiod (SD, $8 \mathrm{~h}$ light, $n=38$ ) or long-day photoperiod (LD, 16 h light, $n=52$ ). The fitted line represents reduced major axis regressions for the pooled data $(n=90)$. 


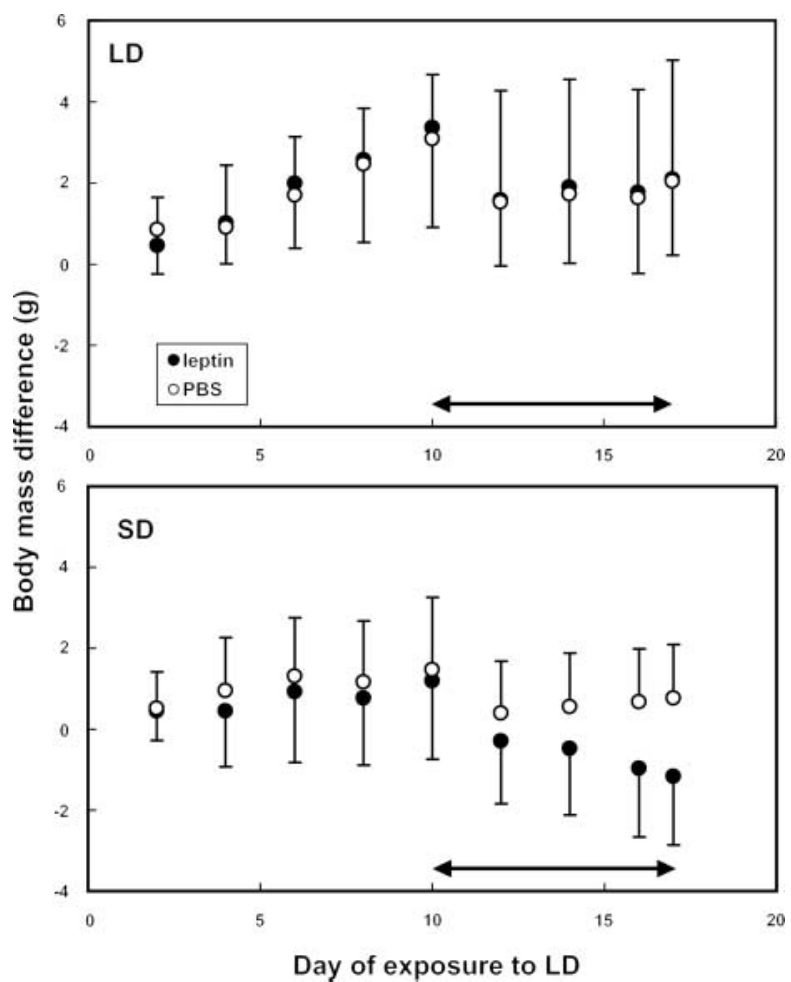

Figure 5 Mean body mass difference from the base line for leptinand PBS-infused male field voles exposed to long- (LD, $16 \mathrm{~h}$ light) and short-day (SD, $8 \mathrm{~h}$ light) photoperiod ( $n=9$ for each group). Day 0 is the day of exposure to LD. Mini-osmotic pumps were implanted on day 10, after recording body mass. The base line was calculated for each vole as a mean body mass prior to exposure to LD (days -4 to 0 ). Arrows indicate period of leptin/PBS infusion. Error bars represent 1 S.D.

$6 \cdot 8 \pm 0 \cdot 9$ (SD-leptin) and 6.3 $\pm 0 \cdot 8$ (SD-PBS) g/day (Fig. 6). Prior to leptin treatment (days 2-10), the LD and SD voles did not differ in their food intake. This is consistent with our previous results, which indicated that the food intakes of LD and SD voles were not significantly different until day 18 of exposure to LD (above and Król et al. 2005). All voles responded to the implantation of mini-osmotic pumps by decreasing their food intake on day 12 compared with day 10 . In LD and SD voles infused with PBS, this decrease averaged $0 \cdot 9 \pm 0 \cdot 8$ and $0 \cdot 9 \pm 1 \cdot 0 \mathrm{~g} /$ day respectively. Between days 14 and 17, the food intake of LD and SD voles infused with PBS returned to the level observed prior to surgery. In LD photoperiod, changes in food intake of leptin-infused voles over days 2-17 were similar to the changes observed in PBSinfused controls. In the SD photoperiod, however, the response of leptin-infused voles was significantly different to PBS-infused animals $(P=0 \cdot 041)$. Specifically, SD leptin- and PBS-infused voles did not differ in food intake between days 2 and $12(P>0 \cdot 05)$, but on days 14-17, the voles infused with leptin ate significantly less food than those infused with PBS (day 14, $P=0 \cdot 022$; day $16, P=0 \cdot 016$; day $17, P=0 \cdot 030$ ). Over the 7-day leptin treatment (days 10-17), the difference

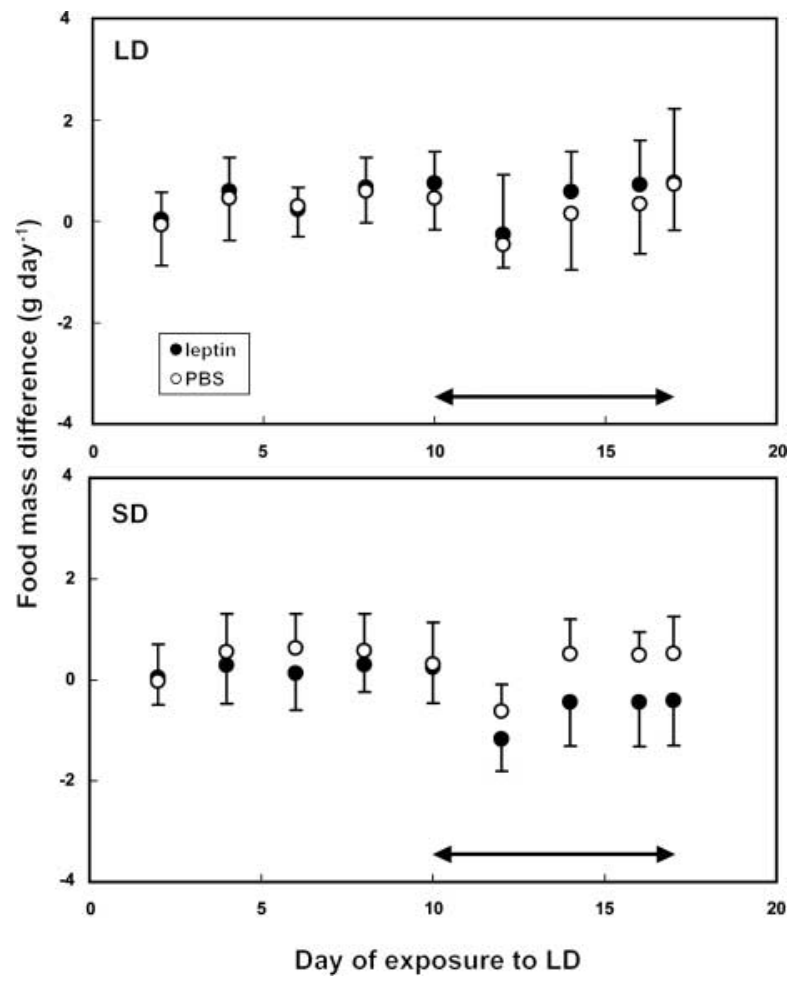

Figure 6 Mean food intake difference from the base line for leptinand PBS-infused male field voles exposed to long- (LD, $16 \mathrm{~h}$ light) and short-day (SD, $8 \mathrm{~h}$ light) photoperiod ( $n=9$ for each group).

Day 0 is the day of exposure to LD. Mini-osmotic pumps were implanted on day 10 , after recording food intake. The base line was calculated for each vole as a mean food intake prior to exposure to LD (days -4 to 0 ). Arrows indicate period of leptin/PBS infusion. Error bars represent 1 S.D.

between mean absolute food intakes of SD PBS- and leptininfused voles was $2 \cdot 5 \mathrm{~g}$.

\section{Neuroendocrine correlates of leptin sensitivity and resistance}

We examined hypothalamic $A R C$ gene expression of suppressor of cytokine signalling-3 (SOCS3) and four leptin-responsive neuropeptides that are important to energy homeostasis - neuropeptide Y (NPY), agouti-related peptide (AgRP), proopiomelanocortin (POMC) and cocaine- and amphetamine-regulated transcript (CART). mRNA levels were quantified by in situ hybridization in $20 \mu \mathrm{m}$ coronal sections using techniques described previously (Simmons et al. 1989, Mercer et al. 1995, 1997). Antisense riboprobes complementary to fragments of hamster SOCS3 (Tups et al. 2004), rat NPY (Mercer et al. 1995), hamster AgRP and POMC (Mercer et al. 2000) and rat CART (Adam et al. 2000) were transcribed from cloned cDNA templates. Coronal hypothalamic sections of vole brains were cut on a cryostat and collected throughout the extent of the ARC onto a set 


\section{$\operatorname{socs} 3$}

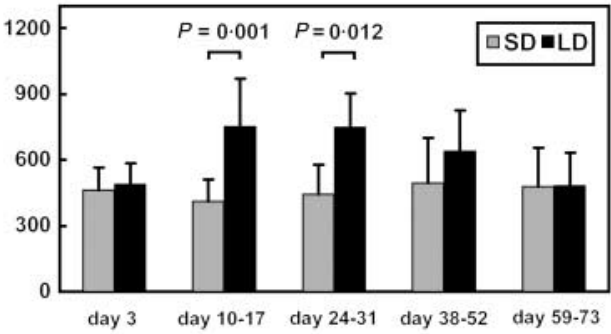

NPY

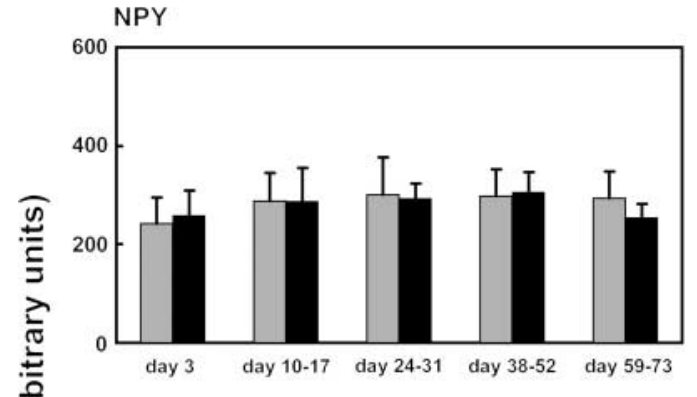

\section{AgRP}

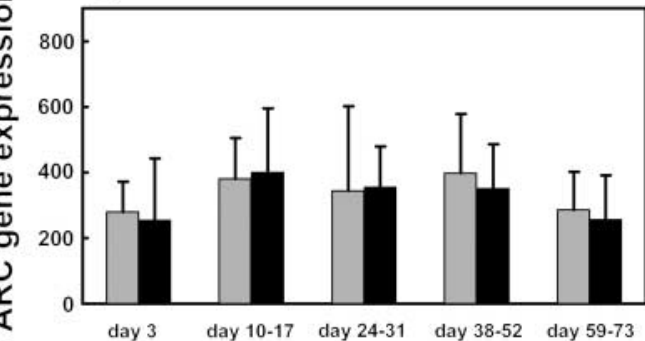

POMC

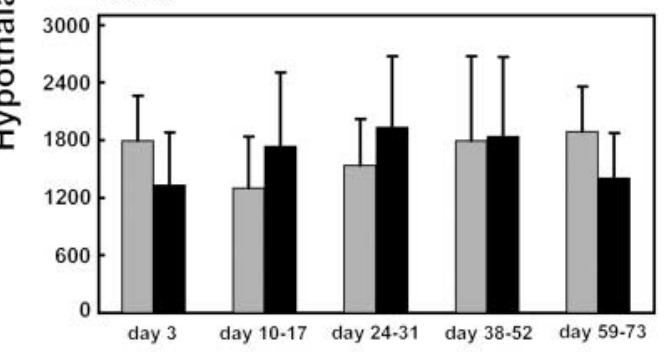

CART

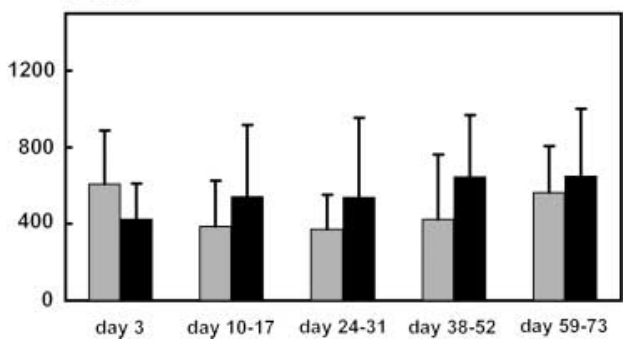

of eight slides, with six or seven sections mounted on each slide. Autoradiographic images were quantified using the Image-Pro Plus system (Media Cybernetics, Silver Spring, $\mathrm{MD}$, USA). Image analysis was performed on four to five sections for SOCS3, NPY, AgRP and POMC, and on three to four sections for CART. Final results were expressed as the mean value of the three highest readings (SOCS3, NPY, AgRP and POMC) or as the mean value of the two highest readings (CART).

The distribution of SOCS3, NPY, AgRP, POMC and CART mRNAs in the field vole hypothalamus was consistent with other rodent species (Mercer et al. 2000, Peacock et al.2004, Tups et al. 2004). Although the probe for SOCS3 hybridized to the ARC, ventromedial and dorsomedial nuclei, expression outside the ARC was highly variable and generally not strong enough to allow quantification by image analysis. Apart from SOCS3, the ARC was also the main expression site for NPY, AgRP and POMC mRNAs. CART mRNA was widespread throughout the hypothalamus and also strongly expressed in the ARC.

Hypothalamic ARC gene expression of SOCS3, NPY, AgRP, POMC and CART was highly correlated with dry fat mass. The correlation was positive for SOCS3 $(r=0 \cdot 62$, $P<0.001)$ and catabolic neuropeptides POMC $(r=0.47$, $P<0.001)$ and CART $(r=0.52, P<0.001)$, but negative for anabolic neuropeptides NPY $(r=-0 \cdot 59, P<0 \cdot 001)$ and AgRP $(r=-0.56, P<0 \cdot 001)$. There was a significant effect of photoperiod on the hypothalamic $A R C$ gene expression of SOCS3 (dry fat mass, $P<0 \cdot 001$; photoperiod, $P<0 \cdot 001$; day of exposure, $P=0 \cdot 105$; interaction photoperiod $X$ day, $P=0 \cdot 005$; Fig. 7). As indicated by the significant interaction between photoperiod and day of exposure, temporal changes in SOCS3 mRNA in LD voles differed from those in SD voles. At the early stage of exposure (day 3), there was no significant difference in SOCS3 expression between LD and SD voles $(P>0 \cdot 05)$. The levels of SOCS3 mRNA in LD voles then increased to $82 \cdot 4 \%$ above the SD levels on days $10-17$ $(P=0 \cdot 001)$ and to $69 \cdot 0 \%$ above the SD levels on days $24-31$ $(P=0 \cdot 012)$. However, this increase was not maintained, and on days 38-52 and 59-73, SOCS3 expression in LD voles returned to the same level as in the SD controls $(P>0 \cdot 05)$. In contrast to SOCS3, expression of AgRP, NPY, POMC and CART was unaffected by photoperiod or day of exposure.

\section{Discussion}

Seasonal body mass changes in field voles are characterized by a clear delineation between two levels where animals regulate

Figure 7 Hypothalamic ARC gene expression of SOCS3, NPY, AgRP, POMC and CART in male field voles exposed to either short- (SD, $8 \mathrm{~h}$ light) or long-day (LD, $16 \mathrm{~h}$ light) photoperiod for 3, 10-17, 24-31, $38-52$ and $59-73$ days ( $n=90$ in total). Data are least squares means adjusted to a common dry fat mass of $2 \cdot 0309 \mathrm{~g}(n=90)$. P values indicate significant differences between the means, as assessed by Tukey post hoc comparisons. Error bars represent 1 S.D. 
their body mass and body fatness, and by the rapid rate at which they switch between these levels (Król et al. 2005; Fig. 1). During this transition in adiposity, serum leptin concentrations increase as a direct function of dry fat mass. The highly significant positive correlation between leptin levels and dry fat mass (Fig. 4) is consistent with the similar pattern observed in many other species (e.g. Frederich et al. 1995, Considine et al. 1996, Wolden-Hanson et al. 1999) as well as the potential role of leptin as an adipostatic signal (e.g. Friedman \& Halaas 1998, Woods et al. 2000). Therefore, the absence of a response to the increasing levels of adiposity was not because the voles modulated the peripheral production of leptin. This observation corresponds with similar patterns observed in other seasonal mammals (e.g. Drazen et al. 2000, Concannon et al. 2001, Johnson et al. 2004, Li \& Wang 2005).

Peripheral infusion with murine leptin for 7 days through mini-osmotic pumps, allowed us to demonstrate that SD voles are sensitive to both weight-reducing and appetite-reducing effects of leptin (Król et al. 2006). Conversely, LD voles infused with leptin between days 10 and 17 of exposure showed no significant response, indicating a state of leptin resistance. The changes in responsiveness to leptin treatment induced by photoperiod were similar to those observed in Siberian hamsters (Atcha et al. 2000, Klingenspor et al. 2000, Rousseau et al. 2002). A novel aspect of our study is the demonstration that the development of leptin resistance in voles starts as early as 10-17 days, following transfer from SD to LD. In contrast, comparable studies of Siberian hamsters focused on the changes in leptin sensitivity that occurred at least 8 weeks after the photoperiod switch (Atcha et al. 2000, Klingenspor et al. 2000, Rousseau et al. 2002). In voles, the period between days 10 and 17 of exposure to LD corresponded with the highest increase in hypothalamic $A R C$ gene expression of SOCS3, an inhibitor of intracellular leptin signalling, which rose to $82 \cdot 4 \%$ above the SD levels (Fig. 7). The simultaneous occurrence of a diminished responsiveness to leptin along with hypothalamic induction of SOCS3 and rapid body mass increase in LD voles, clearly suggests that their resistance to leptin may involve SOCS3mediated inhibition of the leptin signal.

The importance of SOCS3 in mediating seasonal changes in leptin sensitivity may be more generally applicable. Specifically, transfer of male Siberian hamsters from LD to SD conditions was associated with rapid down-regulation of hypothalamic SOCS3 mRNA followed by a decrease in body mass (Tups et al. 2004), whereas transfer back from SD to LD induced an increase in SOCS3 expression that preceded any changes in body mass by at least 2 weeks (Tups et al. 2006). Furthermore, neural cell-specific SOCS3 conditional knockout mice have greater responsiveness to the weight- and appetite-reducing effects of exogenous leptin than their wild-type littermates (Mori et al. 2004). Enhanced leptin sensitivity and attenuation of diet-induced obesity are also observed in mice with heterozygous SOCS3 deficiency (Howard et al. 2004). Finally, leptin-resistant lethal yellow $\left(\mathrm{A}^{\mathrm{y}} / \mathrm{a}\right)$ mice (Bjørbaek et al. 1998), diet-induced obese C57BL/6J mice (Münzberg et al. 2004) and age-induced obese F344 X BN (Scarpace et al. 2002) and Wistar (Peralta et al. 2002) rats have all been shown to have excessive hypothalamic expression of SOCS3, indicating its importance in aetiologically different forms of obesity.

There is also growing evidence that SOCS3 may modulate central leptin action by changing transcriptional activity of leptin-responsive genes (Mori et al. 2004, Higuchi et al. 2005, Münzberg \& Myers 2005). However, in spite of substantial increases in SOCS3 gene expression in the ARC of voles exposed to LD, we found no significant changes in the hypothalamic expression of mRNA for NPY, AgRP, POMC and CART genes. Changes in NPY, AgRP, POMC and CART were also not detected in our previous studies, where bank voles (Clethrionomys glareolus) were exposed to SD or LD for 12 weeks (Peacock et al. 2004). However, these changes in the first-order neuropeptides believed to control food intake were perhaps not surprising because we have also shown that exposure to LD did not significantly affect food intake, once differences in body mass were accounted for (Peacock et al. 2004, Król et al. 2005). Rather, the increase in mass and adiposity was mediated primarily by an increase in digestive efficiency. The nature of the potential link between leptin signalling in the ARC, its inhibition by SOCS3, and digestive efficiency remains unclear. However, possible links between central leptin action and digestive efficiency have also been inferred in arctic ground squirrels Spermophilus parryii (Boyer et al. 1997) and Siberian hamsters (Klingenspor et al. 2000). This is a potentially important finding because differences in digestive efficiency between individuals as a contributing cause of obesity in humans are almost universally ignored.

\section{Conclusions}

Our data on field voles suggest that changes in expression of SOCS3 in the ARC may contribute to the phenomenon of photoperiod-induced changes in leptin sensitivity, and perhaps underpin leptin resistance in other situations such as human obesity. Moreover, our results imply that the transfer of animals from SD to LD alters the defended level of body mass and adiposity. The seasonal changes in the body mass set point, the modulation of the leptin signal by SOCS3 and the important role of changes in digestive efficiency in field voles provide an interesting model system that may allow us to study mechanisms contributing to the development of obesity in humans.

\section{Acknowledgements}

We are grateful to Julian Mercer and Peter Morgan of the Rowett Research Institute for their collaboration on the neuropeptide work. This work was supported by BBSRC grant 1/S1280 awarded to J R S, Peter Morgan and Julian Mercer, and BBSRC grant BB/C504794/1 awarded to J R S and $\mathrm{E} \mathrm{K}$. The authors declare that there is no conflict of interest that would prejudice the impartiality of this scientific work. 


\section{References}

Adam CL, Moar KM, Logie TJ, Ross AW, Barrett P, Morgan PJ \& Mercer JG 2000 Photoperiod regulates growth, puberty and hypothalamic neuropeptide and receptor gene expression in female Siberian hamsters. Endocrinology 141 4349-4356.

Atcha Z, Cagampang FR, Stirland JA, Morris ID, Brooks AN, Ebling FJ, Klingenspor M \& Loudon AS 2000 Leptin acts on metabolism in a photoperiod-dependent manner, but has no effect on reproductive function in the seasonally breeding Siberian hamster (Phodopus sungorus). Endocrinology 141 4128-4135.

Bartness TJ \& Wade GN 1985 Photoperiodic control of seasonal body weight cycles in hamsters. Neuroscience and Biobehavioral Reviews 9 599-612.

Bartness TJ \& Goldman BD 1988 Effects of melatonin on long-day responses in short-day housed adult Siberian hamsters. American Journal of Physiology 255 R $823-\mathrm{R} 830$.

Bartness TJ, Demas GE \& Song CK 2002 Seasonal changes in adiposity: the roles of photoperiod, melatonin and other hormones, and sympathetic nervous system. Experimental Biology and Medicine 227 363-376.

Berthoud HR 2002 Multiple neural systems controlling food intake and body weight. Neuroscience and Biobehavioral Reviews 26 393-428.

Bjørbaek C, Elmquist JK, Frantz JD, Shoelson SE \& Flier JS 1998 Identification of SOCS-3 as a potential mediator of central leptin resistance. Molecular Cell 1 619-625.

Boyer BB, Ormseth OA, Buck L, Nicolson M, Pelleymounter MA \& Barnes BM 1997 Leptin prevents posthibernation weight gain but does not reduce energy expenditure in arctic ground squirrels. Comparative Biochemistry and Physiology. Part C, Pharmacology, Toxicology and Endocrinology 118 405-412.

Campbell CS \& Tabor J 1983 Small effect of brown adipose tissue and major effect of photoperiod on body weight in hamsters (Mesocricetus auratus). Physiology and Behavior 30 349-352.

Concannon P, Levac K, Rawson R, Tennant B \& Bensadoun A 2001 Seasonal changes in serum leptin, food intake, and body weight in photoentrained woodchucks. American Journal of Physiology. Regulatory, Integrative and Comparative Physiology 281 R951-R959.

Considine RV, Sinha MK, Heiman ML, Kriauciunas A, Stephens TW, Nyce MR, Ohannesian JP, Marco CC, McKee LJ, Bauer TL et al. 1996 Serum immunoreactive-leptin concentrations in normal-weight and obese humans. New England Journal of Medicine 334 292-295.

Dark J, Zucker I \& Wade GN 1983 Photoperiodic regulation of body mass, food intake, and reproduction in the meadow vole (Microtus pennsylvanicus). American Journal of Physiology 245 R334-R338.

Drazen DL, Kriegsfeld LJ, Schneider JE \& Nelson RJ 2000 Leptin, but not immune function, is linked to reproductive responsiveness to photoperiod. American Journal of Physiology. Regulatory, Integrative and Comparative Physiology 278 R1401-R1407.

Drazen DL, Jasnow AM, Nelson RJ \& Demas GE 2002 Exposure to short days, but not short-term melatonin, enhances humoral immunity of male Syrian hamsters (Mesocricetus auratus). Journal of Pineal Research 33 118-124.

Ebling FJP 1994 Photoperiodic differences during development in the dwarf hamsters Phodopus sungorus and Phodopus campbelli. General and Comparative Endocrinology 95 475-482.

Frederich RC, Hamann A, Anderson S, Lollmann B, Lowell BB \& Flier JS 1995 Leptin levels reflect body lipid content in mice: evidence for dietinduced resistance to leptin action. Nature Medicine 1 1311-1314.

Friedman JM \& Halaas JL 1998 Leptin and the regulation of body weight in mammals. Nature 395 763-770.

Heldmaier G \& Steinlechner S 1981 Seasonal control of energy requirements for thermoregulation in the Djungarian hamster (Phodopus sungorus), living in natural photoperiod. Journal of Comparative Physiology 142 429-437.

Heymsfield SB, Greenberg AS, Fujioka K, Dixon RM, Kushner R, Hunt T, Lubina JA, Patane J, Self B, Hunt P et al. 1999 Recombinant leptin for weight loss in obese and lean adults: a randomized, controlled, doseescalation trial. Journal of the American Medical Association 282 1568-1575.
Higuchi H, Hasegawa A \& Yamaguchi T 2005 Transcriptional regulation of neuronal genes and its effect on neural functions: transcriptional regulation of neuropeptide Y gene by leptin and its effect on feeding. Journal of Pharmacological Sciences 98 225-231.

Howard JK, Cave BJ, Oksanen LJ, Tzameli I, Bjørbaek C \& Flier JS 2004 Enhanced leptin sensitivity and attenuation of diet-induced obesity in mice with haploinsufficiency of Socs3. Nature Medicine 10 734-738.

Hunter HL \& Nagy TR 2002 Body composition in a seasonal model of obesity: longitudinal measures and validation of DXA. Obesity Research 10 1180-1187.

Johnson MS, Onorato DP, Gower BA \& Nagy TR 2004 Weight change affects serum leptin and corticosterone in the collared lemming. General and Comparative Endocrinology 136 30-36.

Kennedy GC 1953 The role of depot fat in the hypothalamic control of food intake in the rat. Proceedings of the Royal Society of London. Series B. Biological Sciences 140 578-592.

Klingenspor M, Dickopp A, Heldmaier G \& Klaus S 1996 Short photoperiod reduces leptin gene expression in white and brown adipose tissue of Djungarian hamsters. FEBS Letters 399 290-294.

Klingenspor M, Niggemann H \& Heldmaier G 2000 Modulation of leptin sensitivity by short photoperiod acclimation in the Djungarian hamster, Phodopus sungorus. Journal of Comparative Physiology $17037-43$.

Król E, Redman P, Thomson PJ, Williams R, Mayer C, Mercer JG \& Speakman JR 2005 Effect of photoperiod on body mass, food intake and body composition in the field vole, Microtus agrestis. Journal of Experimental Biology 208 571-584.

Król E, Duncan JS, Redman P, Morgan PJ, Mercer JG \& Speakman JR 2006 Photoperiod regulates leptin sensitivity in field voles, Microtus agrestis. Journal of Comparative Physiology 176 153-163.

Król E, Tups A, Archer ZA, Ross AW, Moar KM, Bell LM, Duncan JS, Mayer C, Morgan PJ, Mercer JG et al. 2007 Altered expression of SOCS3 in the hypothalamic arcuate nucleus during seasonal body mass changes in the field vole, Microtus agrestis. Journal of Neuroendocrinology 19 83-94.

Levin BE \& Keesey RE 1998 Defense of differing body weight set points in diet-induced obese and resistant rats. American Journal of Physiology. Regulatory, Integrative and Comparative Physiology 274 R412-R419.

Li XS \& Wang DH 2005 Regulation of body weight and thermogenesis in seasonally acclimatized Brandt's voles (Microtus brandti). Hormones and Behavior 48 321-328.

Mercer JG \& Speakman JR 2001 Hypothalamic neuropeptide mechanisms for regulating energy balance: from rodent models to human obesity. Neuroscience and Biobehavioral Reviews 25 101-116.

Mercer JG, Lawrence CB, Beck B, Burlet A, Atkinson T \& Barrett P 1995 Hypothalamic NPY and prepro-NPY mRNA in Djungarian hamsters: effects of food deprivation and photoperiod. American Journal of Physiology. Regulatory, Integrative and Comparative Physiology 269 R1099-R1106.

Mercer JG, Lawrence CB, Moar KM, Atkinson T \& Barrett P 1997 Short-day weight loss and effect of food deprivation on hypothalamic NPY and CRF mRNA in Djungarian hamsters. American Journal of Physiology. Regulatory, Integrative and Comparative Physiology 273 R768-R776.

Mercer JG, Moar KM, Ross AW, Hoggard N \& Morgan PJ 2000 Photoperiod regulates arcuate nucleus POMC, AGRP, and leptin receptor mRNA in Siberian hamster hypothalamus. American Journal of Physiology 278 R271-R281.

Mercer JG, Moar KM, Logie TJ, Findlay PA, Adam CL \& Morgan PJ 2001 Seasonally-inappropriate body weight induced by food restriction: effect on hypothalamic gene expression in male Siberian hamsters. Endocrinology 142 4173-4181.

Montague CT, Farooqi IS, Whitehead JP, Soos MA, Rau H, Wareham NJ, Sewter CP, Digby JE, Mohammed SN, Hurst JA et al. 1997 Congenital leptin deficiency is associated with severe early-onset obesity in humans. Nature 387 903-908.

Morgan PJ \& Mercer JG 2001 The regulation of body weight: lessons from the seasonal animal. Proceedings of the Nutrition Society 60 127-134.

Morgan PJ, Ross AW, Mercer JG \& Barrett P 2003 Photoperiodic programming of body weight through the neuroendocrine hypothalamus. Journal of Endocrinology 177 27-34. 
Mori H, Hanada R, Hanada T, Aki D, Mashima R, Nishinakamura H, Torisu T, Chien KR, Yasukawa H \& Yoshimura A 2004 Socs3 deficiency in the brain elevates leptin sensitivity and confers resistance to diet-induced obesity. Nature Medicine 10 739-743.

Mrosovsky N 1983 Cyclical obesity in hibernators: the search for the adjustable regulator. In Recent Advances in Obesity Research: IV, pp 45-56. Eds J Hirsch \& TB Van Itallie. London: John Libbey \& Co Ltd.

Münzberg H \& Myers MG Jr 2005 Molecular and anatomical determinants of central leptin resistance. Nature Neuroscience 8 566-570.

Münzberg H, Flier JS \& Bjorbaek C 2004 Region-specific leptin resistance within the hypothalamus of diet-induced obese mice. Endocrinology 145 4880-4889.

Nagy TR 1993 Effects of photoperiod history and temperature on male collared lemmings, Dicrostonyx groenlandicus. Journal of Mammalian Evolution 74 990-998.

Nagy TR \& Negus NC 1993 Energy acquisition and allocation in male collared lemmings (Dicrostonyx groenlandicus): effects of photoperiod, temperature and diet quality. Physiological Zoology 66 537-560.

Nagy TR, Gower BA \& Stetson MH 1994 Photoperiod effects on body mass, body composition, growth hormone, and thyroid hormones in male collared lemmings (Dicrostonyx groenlandicus). Canadian Journal of Zoology 72 1726-1734

Peacock WL, Król E, Moar KM, McLaren JS, Mercer JG \& Speakman JR 2004 Photoperiodic effects on body mass, energy balance and hypothalamic gene expression in the bank vole. Journal of Experimental Biology 207 165-177.

Peralta S, Carrascosa JM, Gallardo N, Ros M \& Arribas C 2002 Ageing increases SOCS-3 expression in rat hypothalamus: effects of food restriction. Biochemical and Biophysical Research Communications 296 425-428.

Reynolds PS \& Lavigne DM 1989 Photoperiodic effects on post-weaning growth and food consumption in the collared lemming Dicrostonyx groenlandicus. Journal of Zoology 218 109-121.

Rosenbaum M, Leibel RL \& Hirsch J 1997 Obesity. New England Journal of Medicine 337 396-407.

Rousseau K, Atcha Z, Cagampang FR, Le Rouzic P, Stirland JA, Ivanov TR, Ebling FJ, Klingenspor M \& Loudon AS 2002 Photoperiodic regulation of leptin resistance in the seasonally breeding Siberian hamster (Phodopus sungorus). Endocrinology 143 3083-3095.

Scarpace PJ, Matheny M, Zhang Y, Shek EW, Prima V, Zolotukhin S \& Tumer N 2002 Leptin-induced leptin resistance reveals separate roles for the anorexic and thermogenic responses in weight maintenance. Endocrinology 143 3026-3035.

Schuhler S \& Ebling FJ 2006 Role of melanocortin in the long-term regulation of energy balance: lessons from a seasonal model. Peptides $\mathbf{2 7}$ 301-309.

Schwartz MW \& Seeley RJ 1997 The new biology of body weight regulation. Journal of the American Dietetic Association 97 54-58.
Schwartz MW, Woods SC, Porte D Jr, Seeley RJ \& Baskin DG 2000 Central nervous system control of food intake. Nature 404 661-671.

Simmons DM, Arriza JL \& Swanson LW 1989 A complete protocol for in situ hybridisation of messenger RNAs in brain and other tissues with radiolabeled single-stranded RNA probes. Journal of Histotechnology 12 169-181.

Speakman JR 2004 Obesity: the integrated roles of environment and genetics. Journal of Nutrition 134 2090S-2105S.

Stallone DD \& Stunkard AJ 1991 The regulation of body weight: evidence and clinical implications. Annals of Behavioral Medicine: a Publication of the Society of Behavioral Medicine 13 220-230.

Stebbins LL 1984 Overwintering activity of Peromyscus maniculatus, Clethrionomys gapperi, C. rutilus, Eutamias amoenus and Microtus pennsylvanicus. In Winter Ecology of Small Mammals, edn 10, pp 201-213. Ed. J Merritt. Pittsburgh: Special Publication of Carnegie Museum Natural History.

Steinlechner S \& Heldmaier G 1982 Role of photoperiod and melatonin in seasonal acclimatization of the Djungarian hamster, Phodopus sungorus. International Journal of Biometeorology 26 329-337.

Tartaglia LA, Dembski M, Weng X, Deng N, Culpepper J, Devos R, Richards GJ, Campfield LA, Clark FT, Deeds J et al. 1995 Identification and expression cloning of a leptin receptor, OB-R. Cell 83 1263-1271.

Tups A, Ellis C, Moar KM, Logie TJ, Adam CL, Mercer JG \& Klingenspor M 2004 Photoperiodic regulation of leptin sensitivity in the Siberian hamster, Phodopus sungorus, is reflected in arcuate nucleus SOCS-3 (suppressor of cytokine signaling) gene expression. Endocrinology 145 1185-1193.

Tups A, Barrett P, Ross AW, Morgan PJ, Klingenspor M \& Mercer JG 2006 The suppressor of cytokine signalling 3, SOCS3, may be one critical modulator of seasonal body weight changes in the Siberian hamster, Phodopus sungorus. Journal of Neuroendocrinology 18 139-145.

Wolden-Hanson T, Marck BT, Smith L \& Matsumoto AM 1999 Crosssectional and longitudinal analysis of age-associated changes in body composition of male Brown Norway rats: association of serum leptin levels with peripheral adiposity. Journals of Gerontology. Series A, Biological Sciences and Medical Sciences 54 B99-B107.

Woods SC, Schwartz MW, Baskin DG \& Seeley RJ 2000 Food intake and the regulation of body weight. Annual Review of Psychology 51 255-277.

Zhang Y, Proenca R, Maffei M, Barone M, Leopold L \& Friedman JM 1994 Positional cloning of the mouse obese gene and its human homologue. Nature 372 425-432.

Received in final form 9 December 2006

Accepted 11 December 2006

Made available online as an Accepted Preprint 13 December 2006 